\title{
ASPECTOS DO FENÔMENO DO CANGAÇO NO NORDESTE BRASILEIRO (IV).
}

(Continuação) .

MARIA CRISTINA RUSSI DA MATTA MACHADO

Pós-graduada em História pela Universidade de São Paulo.

VALORES DOS CANGACEIROS.

O sertanejo nordestino possui, na' essência, três valores que o caracterizam: honestidade, machismo e misticismo.

As condições ambientais, mesológicas, dão insegurança ao sertanejo e lhe determinam atitudes místicas, como meios para enfrentar os percalços que não só a natureza, como as condições econômicas e sociais lhe impõem.

Seu machismo tem origem no início do povoamento, quando penetrou na caatinga. À base do esforço físico, dominou o meio, formando uma cultura onde o homem representa força bruta, cabendo à mulher somente a condição de submissa .

A necessidade de ser honesto lhe foi imposta, tambem no início da colonização, quando o vaqueiro transportou o gado do senhor de engenho para o sertão. Havia verdadeiro pacto de honra entre um e outro, na prestação de serviços, pela honestidade ao acertar as contas e na ajuda do fazendeiro litorâneo ao vaqueiro.

Não tomemos honestidade num plano metafísico. Ela não é intrínseca, mas uma decorrência das condições ambientais, nesse particular, uma relação que se estabelece entre o senhor, munido de todos os meios punitivos, e seu servidor, no caso, o vaqueiro inserto num quadro essencialmente coercitivo, ditado pelas condições de mandonismo individual do senhor-de-engenho.

O Cangaceiro conservou o misticismo e o machismo do sertanejo e mudou o conceito de honestidade. 
Qual a sua moral?

Como sobreviveu à perseguição dos governos?

Consciência do porque dessa vida?

\section{Machismo:}

A rudeza do meio e a sobrecarga emocional que elaboram um perfil humano, necessariamente emprestam, ao cangaceiro, condição subjetiva para enfrentar os percalços de sua vida errante pela caatinga, impondo-lhe, a cada passo, obstáculos que deve vencer, sobretudo amparando-se em suas condições peculiares de homem encouraçado pelas dificuldades, que lhe determinam a forma de existência. Não se entenda machismo como exteriorizações de superficial valentia, mas como firmeza de caráter, propria do homem plasmado por um mundo que lhe é hostil.

Regra geral, o cangaceiro é um valente, ainda que potencial, antes de empunhar suas armas de defesa e agressão, de um grupo familiar humilde.

O cangaceiro, em contacto direto com a natureza, passa a assumir atitudes diferentes das dos outros sertanejos. O simples fato de dormir acampado e ter vida nômade, vai exigir dele um novo comportamento e novos valores.

Passa a cozinhar, a bordar, a usar enfeites, quase da mesma forma que a mulher; usa cabelos compridos, chapeu de aba quebrada, não usa roupa de couro como os sertanejos e carrega, tudo o que tem, no seu próprio corpo. Isto acontece porque as necessidades vão impor nova norma de comportamento ao révoltado.

$O$ fato de os cangaceiros fazerem serviços, tidos na comunidade sertaneja como femininos, decorre de que, quando se vive numa vida rústica e nômade, não é diferenciado o sexo no trabalho.

Acresce que em sua primeira fase, o cangaço não incorporava mulheres, daí a necessidade de ser o homem auto-suficiente; assim, pois, na fase posterior, já era norma do comportamento grupal o exercício de atividades que, habitualmente, são tidas como femininas. E o caso da costura, feita, por ambos os sexos, na sociedade sertaneja; no tocante à indumentária rústica, demandava na sua manipulação maior esforço físico.

A divisão do trabalho é maior, nas sociedades mais complexas, e a separação dos trabalhos estritamente femininos e masculinos é encontrada nas sociedades tradicionais. 
Quando a luta é pela sobrevivência e as dificuldades são enormes, os padrões tradicionais caem, permanecendo o que é ditado pelas injunções naturais.

O cabelo comprido, entre os cangaceiros, tanto pode ser pela promessa feita por Lampião, ao ver seu irmão morto, como para se proteger contra o sol, a exemplo do uso do lenço em volta do pescoço.

Os cangaceiros, de um modo geral, gostavam de ser notados e admirados pelos sertanejos, quando entravam nas cidades. Apreciavam ouvir conversas quando não encontravam resistência e faziam, às vezes, rodas para contar suas proezas.

A par do perfume exagerado, que chegou até mesmo a servir de pista para a polícia, usavam grande quantidade de jóias, ostentando sempre riqueza .

Provavelmente para impor-se à sociedade sertaneja, as jóias e o alarde de suas proezas nas lutas contra os policiais, deviam constituir numa autovaloração para o grupo cangaceiro.

"A indumentária de Lampião" recolhida pelos seus matadores, mostra que o "rei do cangaço" alimentava a preocupação de ostentar riqueza.

Usava grande quantidade de jóias, sobretudo medalhas. Só seu chapéu foi avaliado em quatro contos, na época. Na cartucheira, com incrustações a ouro, a fera do nordeste trazia cento e vinte balas para tiro de fuzil" (1).

\section{FORMAS DE CONVIVENCIA.}

"A cunvivência lá no grupo era os irmãos unido cum respeito. Num pode ixistir um filho melhor hoje em dia prá suas mães do que os rapazes do cangaço daquele tempo. Havia respeito pr'aquele que era chefe. A mulé do chefe era tamém sua chefe, cumo se fosse mãe. Respeitavam, tratavam bem - a maior dedicação do mundo tinham. Se um tinha, todos tinham. Se num tinha p'ra todos, tinha só pr'á um, então num tinha para nenhum, ficava pr'aqueles mais fraco: as mulé. A comida era tudo junto. Era uns irmão unidos. Uma mães de família dividia pra seus filhos pequenos: era os grupos, os seus chefes, os seus cabras" (2).

(1). - Jornal $\boldsymbol{A}$ Tarde da Bahia - sexta-feira - 12 de agôsto de 1938.

(2). - Depoimento de Sérgia da Silva Chagas, vulgo "Dadá". 
Isso não quer dizer que não havia desavenças entré os elementos dos bandos. Não existia, contudo, meio-têrmo. Ou o cangaceiro era morto pelo companheiro por falta grave ou, na maioria das vezes, o problema era contornado.

"Nóis us cangaceiro às veis se apurrinhava uns cum os outo, mas porém sem consequença. I logo que nóis si alembrava qui nóis era cumpade, adeus zangação. Cumpade é cumpade" (3).

$E$ eles davam realmente muita importância a esse tipo de relacionamento e, maior ainda, ao parentesco sanguíneo.

Nenhum cangaceiro cobraria um dívida qualquer de um sertanejo, se este estivesse acobertado, por parentesco qualquer, com outro cangaceiro.

"Nóis tava num lugá pro nome Rio Sá quando apareceu um véio todo melado de sangue pruquê tinha apanhado de Zé Bahiano e mi falou:

- Meu fio, cuma é qui v'ancê deixa fazê isso comigo? Eu sou seu tio.

Peguei meu tio i levei prá perto di Lampião.

- Capitão. Zé Bahiano cum otos cabas tá querendo matá êsse home $i$ eu num quero não, qui êle é meu tio. de Deus?

- Mas pruque vancê num. dixe qui êle é seu tio, home

- Cumpade. Ninguém vai incostá a mão nêle, não, pruquê eu vô sê obrigado a fazê uma bestera danada.

E ninguém tocô mesmo" (4).

Para preservar a unidade do bando ou assegurar-se condições vantajosas de sobrevivência, Lampião era levado muitas vezes a fazer concessões e, até mesmo, a poupar pessoas que o haviam prejudicado de alguma forma.

Muitas outras passagens semelhantes ocorreram naquele ambiente:

"Um primo meu de nome Totonho quảxi mórri nas mãos d'uns cabras de Corisco si eu num chegasse a tempo.

- Qui é qui vocês tá fazendo cum o minino?

- Esse é um caba safádo delatô.

(3). - Depoimento de Ângelo Roque, vulgo "Labareda".

(4). - Idem, idem. 
- Esse aqui não. Ele é gente decente. E meu primo e ninguém vai fazê nada cum êle não. Estóro o miolo do primeiro que incostá. E o nigócio terminou ali mesmo" (5).

José Maria de Souza, hoje residente em Malhada Caiçara, Estado da Bahia, ex-coiteiro de Lampião, contou igualmente um episódio ocorrido por volta de 1930:

- "Um dia Lampião disse que ia matar um parente meu "divagá pro mode de num maltratá". Eu pedi pro capitão num matar e disse:

- Num mate não e vou lhe contar pruquê. O senhor vai e mata. Eu mora lá e dispois que o senhor fizer o serviço a fôrça bota em cima do senhor, dispois o senhor faz o serviço cum os outros e não bole comigo, nem com minha famia e a fôrça vai saber que eu presto órdens pro senhor. Aí êle falou:

— E, tem razão. Num vou lá não".

Existiam certas frases milagrosas, usadas pelos chefes de bandos, ou mesmo outros cangaceiros, para evitar as brigas sangrentas entre componentes dos diversos grupos.

"A gente já veve tudo disgraçado, priciguido prá danado pelos macaco e dois home cuma vanceis, mode uma bestera, querem se acabá prá dá gosto a êles? Vão tê juízo, homes de Deus"!

Esse chavão foi usado por Lampião ao apartar uma briga prestes a acontecer entre Labareda e Zé Bahiano. Tudo começara porque Zé Bahiano tentou violentar uma infeliz menina de 15 anos, tentando arrastá-la para debaixo de uma quixabeira.

A mocinha conseguiu a muito custo escapar do temível cangaceiro e correu em busca do socorro de Labareda, que era o cangaceiro mais próximo, pedindo "pelo amor de Deus para salvá-la". Acobertada por Labareda, mesmo assim Zé Bahiano tentou outra vez arrastá-la:

- "Nêgo - Tu num tá vendo qui a minina tá guardada pur um home? Si você tentá quarque coisa vou ti mandá pro inferno".

Nesse instante houve a intervenção providencial de Lampião para evitar o desfecho iminente.

(5). - Depoimento de José Ribeiro, vulgo "Zé Sereno". 


\section{COMPORTAMENTO DA MULHER.}

A figura feminina é uma compensação aos cangaceiros que vivem na caatinga. A mulher ocupava posição não muito diferente daquela que possuia na comunidade sertaneja. Recebia proteção paternalista dos cangaceiros, participava das brigadas, embora com a única preocupação de se defender e não os acompanhava nas empreitadas mais perigosas, tais como cercar lugarejos, prender soldados para exigir dinheiro etc.

"Mulé nunca vi brigano, era só chorá por nome de santo que eu nunca ouvi falá" (6).

Este depoimento da Saracura teve os protestos de Dadá e dos outros cangaceiros como Labareda, Zé Sereno e até mesmo Zé Rufino, este, chefe de volante. Contestaram dizendo que Dadá lutava e era muito valente. Ouvimos falar o mesmo de Maria Bonita. Essas duas cangaceiras eram mulheres de chefes famosos e permaneceram nesse tipo de vida por vários anos, enquanto as outras permaneceram pouco tempo - dois, três anos - por terem sido mortas - Maria, de Labareda, Nenen, de Luiz Pedro. Outras fugiram como Dulce do Criança e Inacinha, do Galo. Ainda outras entraram no fim do cangaço: Sila, de Zé Sereno, Enedina.... Estas moças não podiam estar acostumadas às lutas, ao contrário de Dadá, que permaneceu treze anos e Maria Bonita, oito anos.

Entretanto, participavam indiretamente das lutas, portando uma arma de cano curto (Mauser), quase sempre para defesa pessoal.

Os cangaceiros gostavam de suas mulheres e não queriam que elas se expusessem demais: eram companheiras e não combatentes.

A mulher ajudou a conter os excessos dos desmandos, humanizando os cangaceiros. O companheirismo dá à mulher uma grande fôrça, que nenhum amigo consegue ter.

"Ninguém como as mulheres, sabe fazer mudar em acontecimentos irresistíveis um ato insignificante e rotineiro.

"A esperança de ver aquela festa quase infantil pôs em agitação o acampamento do cangaço.

"Já anteviam, já ouviam, o aboio cansado e triste do cabloco, se arrastando por entre os espinhos afiados das caatingas e doendo no coração vazio daquela gente.

(6). - Depoimento de Benício Alves, vulgo "Saracura". 
Já enchiam os olhos a figura exótica da dona do Baile, já escutavam os dois Galãs e riam dos passos desengonçados da Onça e do Boi, já cantavam baixinho:

$\hat{o} \hat{o} \delta$ OOOÓ $\hat{o} \hat{o}$

abra a porta meu amo

abra a porta meu amo

E já balançavam o corpo pesado ao ritmo gostoso e sensual do canto rústico que sete mocinhas entoariam gingando as cadeiras, queimando o sangue de desejos:

Abra a porta Rei de França

Abra a porta Rei de França

Vamo adorá Rei Missia

Vamo adorá Rei Missia

"Ao chegar, porém, o monarca dos sertões, a festa humilde parou de susto, apagou-se no ambiente a chama da alegria que cantava no coração daquela gente matuta". Lampião contudo "Ordenou que se respeitasse não só as sete mocinhas virgens do "reisado" como tôdas as senhoras casadas presentes à festa.

$O$ baile rodou numa onda de poeira, tôda a noite, cheirando a perfume barato e fedendo a cachaça e a suor, pegou a manhã do dia seguinte, sem nenhum incidente" (7).

Os cangaceiros participavam - quando podiam, é claro - das festas nos povoados próximos, mas realizavam, também as suas próprias, ao som do realejo, de boca de criança, do Balão ou até mesmo do próprio Lampião.

"Em algumas ocasiōes, a vida era até boa. Tinha muito cabra ingraçado e divirtido. Nóis fazia bailes quando tava sussegado, e quando tinha lua cheia e todos brincava, mas havia muito respeito. A gente dançava com os cangaceiro como 'se fôsse como um irmão" (7a).

Quando se encontravam acoitados nas grotas, que eram seus tetos mais seguros, os homens passavam noites a fio entregues ao jogo de baralho. Jogavam à luz do candieiro, enquanto as mulheres que não tinham muita chance numa roda de jogo (8) saiam do "coito" e, antes $225-6$

(7). - Goes (Joaquim), Lampião, o último dos cangaceiros. Págs.

(7a). - Depoimento de Hilda Ribeiro, vulgo Sila.

(8). - "Maria Bonita" e "Nenén", esposas de Lampião c Luiz ?edro, as vêzes também participavam do carteado, mas não costumavam ficar durante toda noite entregues ao jôgo, como era normal entre os homens. 
de se recolherem ao sono, ficavam ao ar livre conversando sob a claridade do luar, tão belo naqueles sertões longínquos. Trocavam impressões sobre o dia de ontem e sobre o amanhã sempre incerto que as aguardava.

O cangaceiro não perdoava a traição de uma mulher (9), muito embora sua condição de homem fosse resaltada em suas fugas amorosas:

"Home que é home não pode conhecer uma mulé só, mas mulé é diferente" (10). bandos:

Havia de modo geral todo respeito entre os componentes dos

"Maria Bonita abandonou a família seguindo com o bandido e nunca mais a vimos.

- Teria ela andado direito nesta aventura?

- Parece que sim. Nós até pensamos que ela não durasse muito. Na certa enganaria o bandido, com qualquer cabra e seria assassinada... Tal não se deu porém.

- Também seria preciso muita coragem...

- Pois é, aliás, eu já ouvi dizer que entre os cangaceiros há muito respeito nesse sentido" (11).

O comportamento ético dos cangaceiros vinha, de igual forma, imbuido de um sentido utilitário: preservar a unidade orgânica do bando, a fim de lhe assegurar meios eficientes de combatividade. A ação dos cangaceiros era, em todos os planos, ditada por normas de comportamento, por assim dizer, automáticas (normas incorporadas ao valores - valores já cristalizados).

(9). - Zé Bahiano, por exemplo, apaixonou-se por Lídia, impòndo-a ela a condição de companheira. A bela jovem, entretanto, não conseguiu corresponder aos sentimentos do cangaceiro o que a levou a trai-lo com Bem-Te-Vi. O cangaceiro "Bezouro" vendo a cena quis aproveitar-se de Lídia. Recebendo dela a negativa, jurou contar o caso a "Zé Bahiano", quando ele voltasse de uma viagem que estava fazendo com Lampião. "Bezouro". cumpriu a promessa e Lídia confirmou o fato, mas denunciou a atitude do cangaceiro que pretendeu aproveitar-se da situação. "Posso morrê, mas ele num vai me possui". Lampião, posto a par da verdade, deu um salto, abriu a cabeça (com seu longo punhal) de Bezouro. Lídia também foi morta a pauladas, por Zé Bahiano, que a partir dai tornou-se feroz e vingativo, marcando com suas iniciais "J. B." o rosto, seios, nádegas, das sertanejas que caiam em suas mãos (Relato de Dadá e Zé Sereno).

(10) . - Depoimento de Sérgia da Silva Chagas, vulgo "Dadá".

(11). - Entrevista do Sargento José Miguel, primo de "Maria Bonita", publicada no jornal $A$ Tarde de Salvador, $1^{\circ}$ de agosto de 1938. 
No cangaço não se tolerava o desrespeito à honra da mulher.

"De uma feita houve uma festa na várzea e Lampião convidou todo mundo qué morava naquela região, de légua prá trás prá festa de São João. Foi até a Lagoa do Rancho e convidou Silvestre que disse que não ia e não queria mandar as netas.

Lampião disse:

- Eu sou o responsável pelo que houver.

E foi tudo por conta de Lampião, a comida e a sanfona. Brincaram a noite tôda. Quando foi de manhã, tọdo mundo ia embora e Lampião voltou para Lagoa do Rancho, na casa de Silvestre que estava caminhando de um lado prá outro e dizendo: -

- O cabra "Sabiá" do Curisco me acossou um das netas (11a).

Estacio de Lima em $O$ Mundo Estranho dos Cangaceiros registra o diálogo entre "Labareda" e o velho Silvestre:

"Eu entonce perguntei prá êle:

- Oh! Sirvestre: qui diabo é isso?

Ele mi disse:

- Pruque eu nunca ví ua disgraça dessa, cumo hoje, aqui, in minha casa.

Eu falei:

- U qui foi?

Êle cuntinuô: -

- Um cabra di Lampião forçô ua minina, fia di Juão Cabrêro, neistante.

- Eu perguntei:

- Quem foi u cabra?

- Ele mi arrespondeu:

- Um pru nome de Sabiá.

Apiei-mi du cavalo, apois eu ainda tava amuntado, i siguí para donde tava o cabra. Disse eu pra êle:

- Heim, mi diga uma coisa, Sabiá: cumo você anda fazendo essas perversidade na casa das pessôa cunhicida da gente?

Ele mi disse:

- Anjo Roque, eu mereço é morrê.

Disparei logo a ispingarda in riba dêle $\mathrm{i}$ a bala pegô dérêito,

(11a). - Depoimento de Angelo Roque, vulgo "Labareda". 
i êle morreu sem gemê. Lampião chegô i mi disse: -

- Já matô êsse cachorro?

Deu mais um tiro de parabelo na cabeça dêle, nu chão" (12).

Se as mulheres no cangaço não tinham obrigações com serviços domésticos - mesmo porque essa tarefa era dividida com os "míninos" - sofriam, entretanto, uma série de obstáculos no dia-a-dia de luta contra as volantes. Esses obstáculos se afiguravam muito mais angustiantes, no momento em que elas se encontravam grávidas, principalmente no fim da gestação, quando necessitavam, muitas vezes, de percorrer regiões super-áridas como o Raso da Catarina.

Uma vida que lhes era imposta pelos cangaceiros, que, na maioria dos casos, as raptavam, forçando-as a essas condições (13).

Estando "na vida", a mulher não sentia coragem de sair, primeiramente porque temia represálias por parte dos próprios cangaceiros e, depois, em consequência da ação da volante que a mataria no primeiro lugarejo em que aparecesse.

Vivendo no cangaço e levando consigo todos os valores da mulher sertaneja, a cangaceira nutria verdadeiro pavor pela volante. A simples pronúncia da palavra "macaco" (14) fazia estremecer os sentimentos femininos da mulher no cangaço.

"O mêdo que eu tinha da volante não era mêdo de morrer, porque eu não tenho mêdo de morrer. Eu sei, que todos temos de ter um mesmo caminho de morrer. O meu mêdo era êsse: era quando êles matavam uma mulé, todos aquêles soldados se serviam daquela mulé morta. Até cachorro da volante, dêsses que era nojento, êles excitavam aqquêle cachorro prá se ter cum aquela mulé. O mêdo que eu tinha era êsse, porque esse causo de desrespeito eu sempre tive mêdo" (15).

Foi a partir de 1930 que a mulher começou a ter acesso aos bandos. Nessa época Lampião conheceu Maria de Déa e, pela primeira vez na sua vida nômade, permitiu o ingresso do elemento feminino nos grupos.

(12). - Lima (Estácio de), O mundo estranho dos cangaceiros, págs. 210 e 211.

(13) . - Sérgia da Silva Chagas, vivia com seus pais em Queimada, sertão da Bahia. Corisco apaixonou-se pela jovem; sabendo que não teria consentimento do pai da moça, rapta a jovem de 13 anos.

(14). - "Macaco" - era o apelido dado pelos cangaceiros aos homens da polícia, contratados para persegui-los.

(15). - Depoimento de Sérgia da Silva Chagas, vulgo "Dadá". 
Anteriormente o cangaceiro poderia ter uma companheira que, contudo, não lhe seguia os passos, permanecendo na casa de algum parente (16).

Notamos, a partir de então, uma mudança no comportamento dos grupos, porque elas representavam um certo freio em relação às atitudes dos homens cangaceiros, sob o ponto de vista moral e ético. Antes de 1930, a simples entrada de um bando de homens nas cidades, mesmo quando estes não demonstravam atitudes agressivas, provocava maior temor à população e, se eles encontrassem um ambiente propício e tivessem alguma irritação contra as pessoas do lugar, praticavam verdadeira chacina, tentando desmoralizar os padrões familiares. Veja-se o relato de João Siqueira (17):

"Ia êle descendo perto do Pombal, na Paraíba, quando avistou um padre e um bocado de gente atrás dêle. Pensou que fôsse "macaco", se amoitou e na passagem agarrou um home e perguntou:

- Qui tropa é essa qui vai aqui?

- Não é soldado não. E um casamento qui vem aqui da Barroca .

Lampião ficou alegre e disse:

- E longe a festa?

- Não, é perto - respondeu o padre.

E Lampião foi também para a festa, mas, quando chegou lá, teve o cuidado de arrodear tudo e prender todo mundo, práver se não tinha volante.

Todo mundo ficou desesperado, mas Lampião entrou na casa, perguntou onde estava o dono da festa e quis ver os noivos. Depois deu ordem prá soltar o pessoá, dizendo:

- Vamos fazê uma festona.

E olhe, a festa foi grande mesmo, foi uma festa danada, e Lampião dançou muito, mas teve cuidado de colocar em cada bôca de entrada, dois cabras que se revesavam. Deu prá todo mundo dançar, mas no fim da festa Lampião fêz uma malvadez, êle deu a ordem:

(16). - "Dadá foi raptada por Corisco em 1928. "Corisco me levou para uns conhecidos dele, uns parente, onde eu fiquei quase tres anos escondida no meio desse povo. Me levou para o brejo do Burgo, onde tinha a tia dele. Depois de uns tres anos mais ou menos, ele voltou, apareceu lá em casa para me ver, já tinha mulé no cangaço: Me levou com ele".

(17). - Ex-coiteiro de Lampião, hoje residente em Euclides da Cunha, Estado da Bahia. 
- Rapaziada. A coisa agora mudou, todo mundo vai dançar nu. E o pessoal não pôde sair porque a casa tava cercada e todo mundo teve de dançar como êle mandou. Depois, êle montou nos animais e disse: -

- Continuem assim até meio dia.

Foi sé êle sair que todo mundo correu prá agarrar as roupas e se vestir ràpidamente.

Fatos como êsses só ocorreram quando a mulher não estava presente. A partir desta época, o cangaço tomou novas formas, porque a mulher imprimia outra imagem ao grupo, reprimindo as arruaças desordenadas, as atrocidades desmedidas, muito embora participasse, indiretamente, de qualquer ação contra a volante e contra os delatores (18).

Paralelamente, elas infundiam maior confiança na população que poderia encontrar nelas um ponto de apoio, e a esperança de que não cometeriam violências.

A mulher deu, certamente, muito maior estabilidade emocional ao homem do cangaço, proporcionando-lhe, outrossim, embora de maneira simples, a incorporação da família no seu novo meio. Mas era uma família a dois, porque os filhos que nasciam naquela região não podiam fazer parte do contexto. Eram eles, então, entregues às famílias amigas, às vezes, até mesmo de "coronéis do sertão", ou algum padre.

(18). - O "cangaceiro Gato", tomando conhecimento de que sua mulher, Inacinha, havia sido morta pela volante, fato esse não comprovado posteriormente, entrou em Piranhas, em 1935, disposto a vingar-se em uma população inocente. Eis o relato de Patrocínio Rodrigues da Silva:

"êle entrou em nossa casa; nós tudo inocente sem saber do que se tratava, eu e minha irmã estava brincando. Aí eu ouví aquelas vozes: "Lavanta minino". Eu olhei pra dentro de casa no terreiro estava completo de cangaceiros. Mas dentro dos acontecimentos todos, só tinha um que fêz os absurdos o foi só mesmo Gato. Ele pediu água e quando ela deu o caneco pra êle e saiu. Ele atirou nela. Pegou papai, puchou prá dentro de um quarto e matou êle. Os cangaceiros não fizeram nada, tudo de cabeça baixa. Eu tinha uma lrmã que antes dele atirar nela, ela gritou: "Não deixe me matar. Olhe as minhas três criancinhas". Aí êle puchou um punhal e sangrou ela. Êle ia matar também as três criancinhas quando apareceu um bandido que pegou duas e pois no fundo da rede e pegou a outra no colo e gritou pra êle: "Pra matar essas crianças, tem qui mi matar primeiro. Uma outra bandida (Dadá) me puxou para o lado e me mandou correr. Corisco espantado com a agressividade do cangaceiro gritou: "Oxente Gato. Vancê ficou lôco! Vancê tem razão de ficar com raiva pro causo do qui fizeru com sua muié, más num adianta matá as famias qui num tem nada com isso. Vá matá as volantes! 
"Conheci Azulão. A mulé dêle teve minino aqui nas caatingas. Ele mandou trazer o minino aqui prá oferecer para o sargento João Nunes, com o seguinte recado:

"Olhe aqui o que Azulão mandou. Disse prá criá bem criadinho que é filho de homem". O sargento disse que não tinha muié e que não podia ficar com o minino. Quis dar para um empregado do Departamento, mas a criança não arresistiu e morreu" (19). Muitas crianças morreram e outras conseguiram sobreviver e foram bem criadas (20).

Nas caatingas só havia lugar mesmo para o casal e, dentro dessa família sui generis, o princípio do machismo continuava inabalavel.

Em 1926 houve a primeira tentativa de integração do cangaceiro à comunidade, quando Padre Cícero convocou Lampião e seus cabras para combater a Coluna Prestes. Esta tentativa ocorreu de fora para dentro do bando de cangaceiros e foi uma consequência circunstancial, visto que as forças legais necessitavam da ajuda do homem da caatinga, para combater os revoltosos. Mas o radicalismo dos pernambucanos, que não queriam aceitar, em hipótese alguma, a "entrada de bandidos" nas forças patrióticas que combatiam os revoltosos, provocou a ira de Lampião e a frustração da tentativa da sua integração à comunidade sertaneja (21).

A segunda tentativa - e esta ocorreu de dentro para fora - registrou-se em 1930, com a entrada da mulher.

(19). - Relato de João Siqueira, hoje residente em Euclides da Cunha .

(20). - Expedita, filha de Lampião, hoje residente em Aracajú, Estado de Sergipe, foi criada por um vaqueiro, amigo de seu pai. Sílvio, Maria do Carno e Celeste, três dos sete filhos de Corisco e Dadá, ficaram respectivamente, com um padre alagoano (o rapaz), e as duas moças com fazendeiros amigos dos cangaceiros. Sílvio Ermano de Bulhões, hoje economista, e residente em Santana de Ipanema, Estado da Bahia, onde viveu desde menino, foi criado pelo Padre Bulhões, e, somente quando Corisco morreu, tomou conhecimento de que era filho do cangaceiro. Interessou-se pelo problema e sabendo, por intermédio de sua mãe, que o maior desejo de seu pai era ve-lo advogado, para poder livra-lo daquela vida, e conduzi-lo à sociedade, passou a partir de então - "dia de sua formatura como economista" - a lutar pela memória do pai, vencendo todos os abstáculos para enterrar a cabeça de Corisco, que se èncontrava exposta no Museu Nina Rodrigues.

(21). - Floro Bartolomeu exigiu do Padre Cícero a colaboração com o governo, dos cangaceiros, contra os revoltosos. O mair guerrilheiro e o que tinha condições para lutar na catinga era Lampião, secundado por seu bando. Padre Cícero não concordava muito com Floro, provavelmente teria ele dado sua opinião ao cangaceiro para não combater a Coluna Prestes, modificando depois seu ponto de vista, ante a possibilidade de reintegrar Lampião à sociedade. 
Com a revolução de 30 , instalou-se na mentalidade do povo, no primeiro momento, uma mística de libertação, a certeza do término dos velhos padrões de dominação; o coronelismo e todas as suas formas de poder seriam extirpados do sertão. O sertanejo, como o brasileiro de um modo geral, respirava aliviado, antevendo a possibilidade de se ver livre de todas as formas de opressão, tão comuns na época.

Esse sentimento cresceu de tal modo, desde o mais humilde campones até atingir Lampião, que teria sofrido a influência dessa mentalidade nova e talvez percebeu assim a possibilidade de se reintegrar à sociedade da qual um dia ele fizera parte.

A integração da mulher nos bandos era uma modificação qualitativa, de perspectivas novas para eles. As famílias não mais temiam violências sexuais. Lampião fazia festas, tornou-se muito menos agressivo e procurou refúgio onde pudesse viver, pacatamente, ao lado de Maria de Déa. Permaneceu, durante onze meses, com alguns dos seus cabras e respectivas companheiras, próximo de Canindé, sem trocar um só tiro com as forças volantes.

Tal atitude marcou a passagem da fase ofensiva dos bandos, para a defensiva. Defensiva, não na forma de luta - da tática —, mas na maneira de proceder com a população, não mais invadindo cidades, vivendo bem com os amigos, com mulheres, com todos, despreocupado, sem matar nem mesmo os soldados baianos.

Os cangaceiros procuravam, assim, com a participação das mulheres, uma cobertura de respeitabilidade; desejavam ser bem vistos pela população. Elas vão permitir sua aceitação pelo povo sertanejo, que passa a ve-los de outra forma. As moças já não temem violências sexuais; sabem que encontram, na mulher-cangaceira, um apôio para pedir clemência, em ocasiões difíceis, junto ao chefe dos bandos.

Quantas vidas foram salvas por interferência da mulher: mas, se eles conseguiram uma trégua nos meses subsequentes à revolução de 30 , isto aconteceu porque as atenções na época estavam sendo desviadas para o sul. Implantado o novo regime, sob Vargas, viu-se que o cangaceiro continuaria sendo combatido em seus efeitos, nunca em suas causas. As formas mais arcaicas de domínio mantiveram-se inabaláveis e o sertanejo permaneceu submisso, nas mãos dos latifundiários.

E a "persiga" recrudesceu, com novos comandos, mas sob os mesmos métodos. Formaram-se novas frentes de combate; os agentes do governo da zona urbana reclamaram medidas governamentais do Poder Central. 
Mas, só depois de implantado o Estado Novo, em 1937, transformando em autoritário o Poder Central, que se voltou contra o Federalismo $e$ as oligarquias regionais, foi que o cangaço passou a ser enfrentado de forma implacavel, até o seu extermínio.

E com a repressão em escala mais elevada, não restou outra alternativa ao cangaceiro senão voltar aos seus métodos anteriores, agora com a presença do elemento feminino.

"No tempo sem persiga, tudo se tinha. Era tudo mais fácil. Cada pessoa ofiricia o melhor prá gente. Tôda gente vivia bem, luxo, vestidos escolhidos, rouparia do jeito que você queria. Cada qual tinha sua montaria escolhida prá fazer beiço nos outros.

"Mas depois que continuou essa persiga, todo mundo tinha mêdo. Se escondia, quando via, corria e denunciava. A gente tinha que se esconder de uma criança até! Porque se via gente diferente ali, ela denunciava. Depois a persiga aumentou ainda mais e num se teve mais sussêgo.

"Nós ficamos no Raso da Catarina; passei uns tempos lá eu e o grupo todo. Foi quando um volante foi lá e atirou no pessoal nosso, no Raso da Catarina. Saiu todo mundo junto e Lampião dizendo que quem tivesse amizade assim aos maridos, podia preparar-se para andá a pé na percata prô lugá que êlle fosse. Quem não quizesse podia im embora para a casa de seus parentes. Que daquele dia em diante a persiga ia ser dura. Então deixaram animais e tudo" (22).

\section{OS VALENTES MERECEM RESPEITO.}

O homem para entrar no cangaço tinha que ser corajoso e se submetia quase sempre a uma espécie de teste, para configuração da sua potencialidade masculina (23).

Os cangaceiros se vangloriavam do seu machismo, principalmente em relação aos homens da volante e, quando queriam po-los à prova,

(22). - Depoimento de Dadá em 15-02-67.

(23). - Depoimento de Sérgia da Silva Chagas, vulgo Dadá:

Lampião, ao ver pela primeira vez o jovem José Lida, como era chamado também "Zé Sereno", disse: - Que deseja esse macaquinho aqui? Foi meu primo Zé Bahiano que respondeu: Capitão, na minha família nunca deu home covarde. O capitão sorriu e disse que era verdade, mas queria ver. Lá perto tinha um descampado, e quando chegava um novo menino, era pra "Volta Seca" desfrutar. Lampião olhou para mim e disse: - descanse um pouco depois vá lutar. Descansei mesmo e depois me agarrei com êle suspendi e joguei no chão. Depoimento de José Ribeiro ex-cangaceiro Zé Sereno. 
atraiam-nos para o Raso da Cätarina, região onde inexistiam as mínimas condições de sobrevivência (24).

Em outras oportunidades, faziam questão de lanças desafios aos homens da polícia, sempre com o testemunho público, para confirmar o prestígio de poderosos, que queriam manter junto à população (25).

$\mathrm{Na}$ sua primeira passagem pela cidade de Capela, no interior sergipano, o bando almoçou numa pensão e Lampião, ao saber que o local era frequentado pelos homens da volante, resolveu deixar um recado em forma de desafio, bem ao seu estilo: -

(24). - Eustáquio Jovino Ribeiro, ex-volante, que era da turma de Luiz Mariano e que participou de uma campanha, onde foi emboscado por Lampião, narra o episódio: "Lá nos passemo sessenta hora sem tomá água e sem comê. Só não morremo de fome por causa do croatá. Acredita, com licença da palavra, que nós bebemo urina de nós mesmo. Lá no Raso têm de tudo ruim. Tem inté onça más não tem água pra mode bebê.

"Os cangaceiros tinha tirado tôda água de uma raiz de umbuzeiro e nós ficamo sem nada. O pior é como a raiz estava no alto, nós deixemo as arma cá embaixo na mata, pra aguentar a subir. Ninguém aguentava carregar as moambas. Era sêde e calor. E num achemo água. Foi um desepero danado. Tava todo mundo doente e com as roupas rasgada. Sorte que Lampião não veio em cima de nóis, porque se tivesse vindo não sobrava nenhum. Desistimo de pegar as arma e voltemo pra Currais dos Bois, caindo aos pedaços". (do livro As Táticas de Guerra dos Cangaceiros, de Christina Matta Machado, pág.r. 125).

Zé Sereno falou sôbre a mesma batalha, mostrando o outro lado, o lado dos cangaceiros:

"Lampião emboscou Luiz Mariano. Lampião e seus cabras penetraram numa localidade chamada Tamanduá na entrada do Raso. Era um boqueirão. Uma espécie de desfiladeiro, com barrancos dos dois lados. Dividiu a turma. Eram 22 cangaceiros colocou 8 no topo do barranco direito e 8 no topo esquerdo. Seis ficaram na boca da saida do desfiladeiro, simulando a única unidade de combate do inimigo para atraí-lo ao interior da emboscada. Luiz Mariano, um dos poucos soldados que conhecia bem os traquejos de Lampião num se arriscou à empreitada: O Cêgo Véio (nome dado a Lampião) quer me pôr em buraco. Num sô tatu! (exclamação transmitida a Zé Sereno pelos seus coiteiros e atribuida a Luiz Mariano). (Do livro As Táticas de Guerra dos cangaceiros de Christina Matta Machado).

(25). - Versos, cantados pelo povo sertanejo, definem bem a evidência dos feitos dos cangaceiros:

"O Lampião estava acoitado

$\mathrm{Na}$ fazenda de Cajàzeiras

a tardina chegou um dos seus coiteiros

avisando a Lampião, Zé Rufino em seu roteiro.

$O$ alevanta rapaziada enquipa, enquipa vamo viajá

pois só me falta uma coluna inteira

Alecrim, Beija-Fulô, Pitombeira e Araçá

O Zé Rufino diz que é valente

mas é um fino corredor

deu uma brigada na fazenda Pedra d'Água

as quatro horas da tarde morreu seu rastejador. 
"Capela, 25, 11 de 29 - Salvi!"

$\mathrm{Eu}$, Capm. irgolino Ferreira Lampião, digo estas para o oficial que aqui passar. Eu tenho persiguição, apois tenho gosto de voces me perseguirem; desculpe as letras, que sou um bandido como vocês chamam.

Aceite lembranças de meu irmão Izequiel, vurgo "Ponto Fino" e de meu cunhado irgino vurgo "Moderno" (26).

O homem corajoso, mesmo sendo seu inimigo, merece respeito. Os cangaceiros desafiavam os valentes, para mostrar sua força, mas respeitavam todos os que demonstrassem espírito de bravura. A coragem é um padrão levado em alta conta pelo sertanejo.

Até mesmo certọs prisioneiros recebiam o perdão dos cangaceiros. Isto ocoreu várias vezes.

"Numa ocasião, "Sabino" - cangaceiro de Lampião - procurava o assassino de seu irmão. Ao encontrá-lo, prendeu-o e, já com o parabelum preparado para atirar, perguntou: -

- Por que você matou meu irmão?

- Eu matei enganado. Ia matar era o senhor. Fui pago para isso.

O cangaceiro, assustado, perguntou quem desejava sua morte e o valente sertanejo respondeu, com calma, à indagação de Sabino.

- Soltem êsse home - ordenou aos cabras que o seguravam homem assim não se mata. Tem que viver prá tirá a raça" (27).

Lampião, muitas vezes, lastimou ter matado alguns dos seus inimigos valentes.

"Em 1929 seu grupo passou pela cidade de Cumbe (28). O tenente João Cândido, sabendo que Lampião viria para cá, veio com uns vinte soldados. Ele vinha atras do bando desde Canudos e seus soldados já não aguentavam mais. Resolveu parar para descansar. O sargento "Bigode de Ouro", no entanto, achava que podia prosseguir e quando soube que Lampião poderia estar em Maçará não pensou duas vêzes. Esse sargento tinha dito que ai pegar Lampião pra dar uma surra de chicote. Dizia prá todo mundo que ia tampar os olhos dêle com seu chapéu e dar uma pisa (surra) muito grande. Quando soube que Lampião passou por aqui e não foi preso achou um absurdo e garantiu que ia pe-

(26). - Góes (Joaquim), Lampião, o último cangaceiro, págs. 67 e 68 .

(27). - Relato de "Zé Sereno", ex-cangaceiro.

(28). - Hoje, cidade Euclides da Cunha, Bahia. 
gá-lo. E foi-se embora atrás do capitão irgulino. Foi com uns soldados até Benevides, onde arrumou alguns animais e se encaminhou para Maçará. No meio do caminho em Curralinho encontrou-se com o bando dos cangaceiros. Ficou espantado porque achou que Lampião iria fugir dêle. Pois bem, Lampião se entrincheirou ràpidamente. Depois entrou numa casinha e passou a atirar nos soldados. E o "Bigode de Ouro" parecendo que queria mostrar valentia foi de peito aberto pra enfrentar Virgulino. Coitado!!! morreu num minuto. Ele e mais dez. Só sobrou um, que depois contou o que ouviu Lampião dizer pros cangaceiros: "Macho igual aquele num é pra se matá. Foi o único "macaco" que se encaminhou prá mim de corpo aberto" (29).

\section{AO LIDER: CORAGEM, VALENTIA E PRESTÍGIÓ SOCIAL.}

“... o bando só se mantém unido à base do prestígio pessoal do seu líder" (30).

Esse pensamento ocorria com o bando de Lampião, o qual sendo o lider maior, dividia com outros a chefia dos diversos grupos espaIhados nas caatingas de oito Estados, confundindo os policiais e a própria população que nunca sabia se ia oú não encontrar Lampião (31). Todos eles agiam como cangaceiros, faziam seus nomes correr sertões, mas a uma ordem de Lampião todos acorriam. "Zé Sereno" e "Dadá" contam que receberam recado para estarem em Angicos, região de Sergipe, onde Lampião morreu. Todos os bandos deveriam se reunir naquele ponto...

"Dadá confirma que "Corisco" e ela foram avisados mas não encontraram canoa para atravessarem o rio São Francisco. (As volantes tinham usado as que haviam). Esperavam amanhecer para atravessar. Lampião costumava agrupar seus comandados e quando notava certas desavenças buscava na luta e recomposição da unidade. "A guerra para êle era uma ciência; mesmo na sua primitiva maneira de comandar os cangaceirs, praticava os ensinamentos de Maquiavel, autor de quem jamais ouviu falar. Um exemplo: Sempre que havia sérios conflitos entre os canga-

(29). - Relato de Luiz Santana de Lima, na época do cangaço, prefeito da cidade de Cumbe, hoje, Euclides da Cunha.

(30). - Hobsbawu (E. J.), Rebeldes Primitivos, pág. 31.

(31). - O jovem Virgulino; quando lutava ao lado de Sebastião Pereira, demonstrou grande poder de percepção, boa pontaria, disposição e capacidade tática, que the valeram a ascenção à liderança do cangaço, o que aconteceu logo depois que Sebastião Pereira resolveu abandonar as caatingas, deslocando-se para o Estado de Mato Grosso. 
ceiros, Lampião promovia imediatamente escaramuças ou missões impossíveis (invadir uma cidade grande, atacar um destacamento militar), para acabar com a discórdia. Dizia que a luta os tornava solidários. Ensinamentos que Maquiavel escreveu em "O Príncipe": "só uma guerra contra outro Estado pode provocar coesão em ocasiões de crise" (32).

E era na época das brigadas, que ele punha em relêvo sua vocação de liderança. Armando planos, rompendo cercos, provocando ciladas ou enfrentando as mais terríveis agruras de um solo inóspito, o chefe demonstrava seu valor e impunha sua condição de lider.

"Lampião tinha qualquer coisa de extraordinário - era sua tática de guerrilha. Quando Mao Tsé Tung fazia guerrilha no remoto Oriente, Lampião o fazia aqui no Brasil muito melhor.

Prá se ter uma idéia, vou contar um fato ligeiro: Um dos grandes inimigos de Lampião era Odilon Flor, porque o Odilon não era valente, era louco, era um homem de uma coragem tremenda, e depois era inimigo de Lampião. Havia divida de sangue entre Odilon Fḷr e o próprio Lampião.

Acontece que Lampião descia do sertão do Curaça, no Estado da Bahia, e os coiteiros avisaram a êle que Odilon Flor estava naquelas imediações. Mas Lampião, sabido que era, com a tática que tinha de guerrilha, precisava so desvencilhar de Odilon Flor, porque êle sabia quem era e quanto pesava Odilon Flor.

Foram dez homens que viajaram de Nazaré, a pedido, para ajudar no combate a Lampião, entre êles o Manuel Flor, Odilon Flor e Euclides Flor. Lampião percebeu que Odilon ia no seu rastro e não fêz questão de escondê-lo. Adiante, ao passar numa encruzilhada avistou uma casinha, que nós aqui chamamos de "testa de bode" (33). Lampião se aproximou e falou para uma velhinha que estava sentada: - Minha tia, tem alguma coisa aí pra se comer? A velhinha respondeu que não tinha não.

- E essa perua aí?

- Bom, meu filho, essa perua tá crua.

Naquela época, uma perua custava 2 mil e quinhentos réis a três mil réis. Ele meteu a mão na mochila e arrancou cinquenta mil réis.

- Mate essa perua, ponha no fogo que nós estamos ali no alto. Daqui a duas ou três horas, nós vem comer a perua.

(32). - Machado (Christina Matta), ob. cit., pág. 65. (Apud Jornal do Brasil, Rio de Janeiro - edição 30 de julho de 1968).

(33). - Casebres de uma só porta, e com o telhado inclinado só para um lado (meia-água, como se diz vulgarmente). 
A velhinha, animada com o dinheiro, preparou a perua e coisa e tal.

E em poucos instantes chegou Odilon Flor naquele mesmo lugar. Foi logo perguntando à velhinha:

- Minha velha, aqui passou um homem de chapéu grande, todo armado?

- Passou não, meu filho.

-. Não é possível, minha velha, nós estamos vindo no rastro dêles.

- Não passaram não. Tão naquele alto. Vem já comê essa perua que me mandaram matar.

Então Odilon estendeu "a fôrça" lá e aguardou a vinda de Lampião.

Aconteceu que um cangaceiro perguntou depois a Lampião:

- O capitão, nós vamos comê a perua, não?

Lampião respondeu:

— Deixa a perua lá brigando com Odilon" (34).

Optatos Gúeiros tambem descreve a tática usada por Lampião, numa portunidade em que se viu cercado pelos tenentes João Gomes, de Pernambuco; Francisco de Oliveira e Adalto, da Paraiba.

O fato ocorreu na Fazenda Serrote Preto, sem haver reação por parte dos atacados:

"Os cangaceiros mataram os dois ficiais parahibanos, dois soldados e romperam o cêrco.

Foram essas fôrças para Mata Grande, cidade mais próxima do local da luta, a fim de submeterem os feridos a tratamento.

As fôrças alagoanas, se aprestaram para seguir os cangaceiros.

Lampeão, conduzindo alguns feridos, chegou à casa de $\mathrm{Ja}$ cinto, com meia légua de Serrote Preto. Aí, encontrou um rapaz de Mata Grande e perguntou:

- Você, donde é?

- Sou de Mata Grande e venho aqui, na casa de José Jacinto tratar de um negócio que temos na compra de peles de bodes-respondeu o alagoano. Lampeão.

- E você não sabe prá onde fi José Jacinto? perguntou

- Ele foi ali, à casa de um amigo, buscar uns couros e deve chegar logo, respondeu.

Nisto, fi chegando José Jacinto.

(34). - Depoimento de Joaquim Góes em Aracajú, Estado de Sergipe, em julho de 1969 . 
Lampeão, na presença do rapaz comprador de couro, disse a José:

- José Jacinto, você vai me arranjar um local por aqui prá você tratar dêsses feridos.

- ah! "seu" capitão, valha-me Nossa Senhora!... não faça uma coisa desta comigo. As fôrças, nestes dois ou três dias, estarão por aqui, e quem vai se desgraçar no pau, sou eu!

Lampeão voltou-se para o alagoano e disse:

- Você conhece êsses caminhos daqui para o Moxotó? deu.

- Pois não, "seu" capitão, eu aqui conheço tudo, respon-

- Pois bem, você vai me ajudar na condução desta rêde, até passarmos a Serra das aras, disse Virgulino".

"Viajaram cinco léguas e quando descambou a Serra das Varas para o Moxotó, disse ao sertanejo alagoano:

- Você pode voltar; se encontrar as fôrças por aí, pode falar a verdade e botá-los no meu rastro.

Deu vinte mil réis ao homem e despediu-o.

Nesta ocasião, chovia um pouco, o que serviu para apagar os vistígios.

Em lugar, porém, de prosseguir viagem, Lampião entrou para a caatinga um quilômetro a dentro e aguardu a passagem de tôdas as tropas, que já vinham com o alagoano como guia e os cangaceiros observaram de perto a passagem do último soldado das tropas que seguiram para o Moxotó e por lá ficaram tateando às apalpadelas e confundidos com tão misterioso desaparecimento.

Enquanto isso, Lampeão, por uma verêda, voltava para a propriedade de José Jacinto, onde tratou de seu pessoal, bem descansadamente e se abasteceu de víveres e medicamentos na próxima - cidade Mata Grande (35).

"Em Missão Velha, passaram na fazenda de Isaias Arruda e pediu Lampeão para, em sua propriedade, passar uns dias, tratando de alguns feridos. Aquele cidadão prontificou-se com a melhor boa vontade a ocultar o grupo e fornecer-lhe tudo o que fôsse necessário, mas a primeira refeição que mandou para os cangaceiros foi "temperada" com veneno. Enquanto faziam aquêle repasto, mandou por fògo na manga ao redor do grupo, deixando sòmente uma pequena passagem e nela foram colocados, bem entrincheirados, alguns homens armados e municiados, para liquidar os que houvessem escapado do veneno e do fogo.

(35).. - Gueiros (Optatos), Lampião, págs. 114, 115 e 116. 
Lampeão viu que daquela vez iria morrer queimado com sua gente, e notando um lugar ainda em condições de se escapar, adivinhou em que espécie de "arapuca" iria cair naquela parte em que ainda não ardia o fogo. Arrastando-se cm a barriga pelo chão, à frente de seus homens, já sentindo os primeiros sintomas do tóxico, que aliás, era fraco, atacando sòmente fortíssima diarréia, irromperam em frente aos da emboscada de Isaias Arruda, com tal violência, que afrouxaram um pouco, 'tendo Lampeão transpôsto o obstáculo, escapando ao fogo, às balas e ao veneno" (36).

\section{MISTICISMO .}

\section{Superstição e Crendice.}

O lider místico do nordeste, tanto pode levar o povo à luta armada, como ao trabalho construtivo ou à inércia e à despreocupação com o mundo que o cerca.

Se o deixam em paz e não o perseguem, seus adeptos vão vindo aos poucos, com o tempo. Se o prendem ou o matam, sua fama cresce logo e sua imagem rompe todas as barreiras, agrupando os fiéis que, sentindo-se psicologicamente amparados, lutam, matam e morrem sem medo. O lider místico é marcado por um traço básico: o carisma. E por força desse carisma, criąo no curso de suas várias formas de comportamento, que ele logra agrupar, ao seu redor, um séquito que the é submisso.

Por isso, o misticismo constitui elemento social de união dos sertanejos não raro envolto em valores religiosos. Um lider civil, apenas com atividades políticas, será, o mais das vezes, aceito por todos, se seu mestre espiritual o aceitar.

Para muitos estudiosos, o fenômeno do misticismo do Nordeste é considerado como fanatismo, nascido da péssima alimentação do sertanejo, que provoca desvios de comportamento (37).

\section{$O$ misticismo entre os cangaceiros.}

$\mathrm{Na}$ verdade, vivendo só, isolado praticamente do seu mundo, em contato direto com a natureza, o cangaceiro sente a necessidade de alguma coisa que o ampare e proteja. Busca então esse apôio no sobrenatural.

(36). - Ibidem, pág. 123.

(37). - Confronto com a obra Geografia da Fome de Josué de Castro (Vol. 2). 
De modo geral, o sertanejo traz no intimo, a esperança de uma felicidade distante. Busca no fantástico religioso a solução de seus problemas. E espera... contudo, apenas espera.

Nesse ambiente de isolamento e atraso, de péssima situação econômica, os dramas sociais começaram a aprofundar-se até atingir seus extremos, com beatos e cangaceiros. No sertão, o messianismo, centralizado no "beato", era animado pelo panorama da seca e da fome e o sertanejo preferia abandonar a terra, o emprego; e ir morrer pelas estradas, faminto e desnutrido.

Sofria no seu intimo, e precisava mais do que nunca comunicar-se com alguém que o compreendesse. Acreditava em Deus e pedia a Sua ajuda. Mas se sentia frustado, dizendo que Deus, evidentemente, não se lembra dos pobres.

Esse ambiente é propício ao surgimento do Beato, homem sempre humilde, falando tudo que o sertanejo pensa falar. Grita, abre os braços, gesticula, pega a cruz e faz dela seu bordão. Montando num "jegue", com barba crescida, voz doce, diz palavras de paz e transmite uma força gigantesca.

O sertanejo olha, pestaneja, quer fugir, está assustado e os pés presos ao solo não o deixam ir. Tem medo, mas o homem aproxima-se, toca-lhe o ombro, e o pranto vem sentido e envergonhado; quer reagir, mostra-se perplexo e hesitante, mas seus joelhos dobram e ele cai, e beija as mãos do desconhecido há tanto tempo esperado.

O sertanejo sente-se protegido. Respeita o homem que para ele é superior. Não está mais sozinho. Suas angustias, suas tristezas, são agora compreendidas.

Sua palavra é lei, sua ordem sentença. Larga a casa ou a roça, ou permanece ligado à terra se o beato quiser, para viver a lutar.

Havia entre os cangaceiros a confluência de todas as formas para o sobrenatural, desde o mstico até as mais simples crendices. $O$ misticismo não se apresentava quimicamente puro - havia um sincretismo religioso. Em vários planos mostrava o cangaceiro a sua fraqueza, diante do incomensuravel, fazendo-o buscar um meio para sobreviver e para dar forças à sua luta .

No ambiente áspero, rude, adverso, quais as formas que ele buscava para defender-se? No sentido genérico, a religiosidade, que envolvia uma série de valores heterogêneos num mundo hostil, era, antes de mais nada, uma arma de defesa e sobrevivência. Por que ficavam na mente dos sertanejos e cangaceiros esses valores, por que 
esse comportamento de religiosidade, que se apresentava com conteudo místico e se desdobrava até as mais elementares crendices? $\mathrm{O}$ que havia de espiritualidade nos cangaceiros?

Estes, frutos de um meio hostil, sentiam a insegurança deste mundo, que lhes incutia na mente todas essas formas supostamente de defesa; o sobrenatural era a máscara de sua fraqueza e aparece sobre os mais variados aspectos: crendices, supertições, e ainda lances de misticismo e religiosidade.

O cangaceiro místico exaltava valores supra-terrenos, em termos de entidades dotadas de poderes sobrenaturais.

Existiam, entre eles, alguns que se curvavam, de mãos levantadas aos céus, pedindo proteção contra a morte que os perseguia. Chegavam mesmo a se afastar do campo de luta, para implorar, a Deus ou a seus santos de devoção, o bom sucesso do empreendimento que estavam realizando.

Era uma atitude de religiosidade do homem ante o perigo.

"Havia um cabra mais nóis, chamado Devoção, i Zé Sereno tomava deboche com êle:

- Quano lhi botaro tá nómi, minino, tu ficô disgraçado. Devoção num é nómi pra home. Só cabra mufino tem êsse vurgo.

"Mas num fogo qui nóis sustentemo adiante, cum us macaco du Sargento du Bizouro, Devoção brigô cuma gente grande i num correu sem orde, mió tarvez que u Zé Sereno. Paricia qui o danado, quiria si amostrá! Nessa brigada Bizouro perdeu pulo meno dois macaco qui morrero baliado.

"Outro cangaceiro qui tava mais nóis nu grupo era $u$ Isperança. Ele brigava bem, mas gostava dimais di rezá. Nessa brigada du Bizouro, quando nóis têve di si arritirá, percuremo u Isperança. Ele tava num cuxixolo di oratório, cum us sóio para riba, qui nem pade dizendo missa. Ele inda mi falô:

- "Ispere pru mim, qui tô na casa véia das oração, reza no pru nóis. Nóis isperemo, qui sempre si arrespeitô us santo, i nóis tinha no pescoço i nus bôtço as reza de maió fiança" (38).

Nas horas mais duras, nos momentos mais difíceis, em meio de uma brigada, ou nas ocasiões em que se viam encurralados, procuravam ajuda através dos Santos, ou de outras forças superiores. Lampião principalmente era, o grande inspirador:

(38). - Cnsultar sobre misticismo: Messianismo no Brasil e no Mundo de Maria Izaura Pereira de Queiroz. 
"A sua religiosidade é feita dé um fetichismo barbaro e abusões catholicas que se condensam em um mysticismo extravagante e selvagem.

"Finge mais superstição do que possue, com o fim de crear emtorno de si atmosphera de mysterio e sobrenatural.

"Como todos os companheiros, traz longos cabellos sobre os hombros, compondo assim uma mascara que atemorisa os soldados, terror que cresce nos tiroteios, com o alarido que fazem os cabras, relinchando, zurrando, latindo, praguejand, chamando por Deus e pelo diabo, a agitar furiosos como incubos as cabelleiras, e a pular como símios. Os soldados crendeiros, que têm nas almas as mesmas supertições, julgam que estão diante do sobrenatural, empolgam-se de pavor, e quando não debandam contidos pela energia férrea do commandante, tiram o olhar de semethante espetáculo, e começam atirar a esmo, sem pontaria, com a cabeça enfiada entre os braços nervosos que empunham a arma sem firmeza" (39).

No Nordeste, notadamente no sertão, o termo "diabo" tem uma dimensão poderosamente estranha. Diz-se que o capeta é capaz de resolver qualquer problema e, às vezes, em condições mais favoráveis que Deus, se necessita de mais almas para seu império instalado no inferno. Toda pessoa que consegue impressionar com ações extraordinárias que fere os padrões tradicionais do povo, passa a pertencer ao domínio do "demônio". Existem várias citações de autores que se preocupam com o problema cangaço e que recorrem aos infernos para verificar certas atitudes de Lampião: "esse home tem parte com o diabo", frase encontrada, particularmente, na literatura de cordel.

$\mathrm{Na}$ realidade, contudo, Lampião provocava temores em seus adversários, que não podiam aceitar certas atitudes do cangaceiro, que orava cotidianamente em plena caatinga, sob os olhares angustiados dos sertanejos, ou das volantes, que não conseguiam entender o gesto senão como um fato extraordinário .

Lampião buscava Deus para pedir ajuda, proteção e para ficar mais forte; e, como lider, estendia a seu grupo a força que ele buscava.

"Alma Estufada de crendices, pescoço a vergar sob o peso de "patuás", irgolino tem como sua mais efficiente mandiga a oração do meio-dia. Se a cavalo perlustra êrma estrada, quando o seu relógio marca as doze horas, êle se apeia $e$, genuflexo na areia

(39). - Lima (Estácio de), O Mundo Estranho dos Cangaceiros; pág. 259. Depoimento de "Labareda". 
quente do caminho, curva a cabeça a comunicar-se com as fôrças misteriosas do Além. Mesmo no mais renhido tiroteio, abandona o fuzil e suplica a não sei que santos ou diabos lhe continuem a conservar o corpo "fechado" (40).

Isso não quer dizer que os cangaceiros, como o sertanejo de um modo geral, apenas usassem as coisas da fé. Traziam, isto sim, dentro de si, uma carga muito poderosa de religiosidade, herdada contudo de pais e avós, sem qualquer outra opção. Uma religião imposta e sem base, se transformava, no cangaceiro, em fetichismo.

Nesse ambiente de crendices e superstições, foi que nasceu e viveu padre Cícero, o "Santo de Joazeiro", como o denominavam os fanáticos, peregrinos que viam nele encarnada a figura de Deus.

Padre Cícero foi amigo pessoal de Lampião, a quem chegou a conceder, por interferência política de Flora Bartolomeu, a patente de capitão.

"O fanatismo avassalava os sertões. O padre Cícero recomendava ao povo que fizesse penitência, para se purificar dos pecados. Aí, os sertanejos começaram a organizar companhias de "penitentes", os quais se flagelavam, reunindo-se a rezar aos pés das cruzes que encontravam, a entoar benditos pelas estradas, visitando as fazendas, em cujas casas era colocado o retrato do "Padre Santo" (41).

Todavia, não era apenas o "padin Ciço" o único sacerdote a merecer deferências por parte dos cangaceiros. Qualquer padre merecia o respeito e a consideração desses homens rudes, que viam neles a maior representação divina na terra.

"O apreço aos sacerdotes em geral não teve descontinuidades. Os cangaceiros não os ofendiam, nem os menosprezavam. Se os topavam em qualquer fazenda, lugarejo, ou estrada, levantavam, no ar, a destra, em gesto simples, e pediam a "benção".

O Reverendíssimo José Bruno da Rocha, nascido em Santo Amaro da Purificação, na Bahia, e Capelão da Igreja do Pôrto da Fôlha, em Sergipe, também era deveras apreciado. Foi êle quem oficiou o casamento de Curisco e Dadá, sabendo muito bem o que fazia.

(40). - Prata (Ranulpho), Lampeão, págs. 27 e 29.

(41). - Mota (Leonardo), No Tempo de Lampião, pág. 18. 
Não menos acatado, o Padre Bulhões de Santana do Ipanema, nas Alagoas (42), homem de atitudes corajosas, em constantes entendimentos com os bandidos, não para tirar vantagens de qualquer sorte, mas para assisti-los com brandura, orientando a educação das crianças que the eram mandadas.

Vários outros mantiveram comportamentos semelhantes, mostrando-se compreensivos e amigos. Poderá dizer-se que, efetivamente, não ocorreram choques, entre cangaceiros e representantes do clero" (43).

Os cangaceiros misturam crucifixos com patuás, agarrando-se a tudo que thes de segurança. Respeitam, aceitam e acreditam nos preceitos da Igreja Católica. Procuram padres ou religiosos e, quando havia oportunidade, chegavam mesmo a se confessar e a se comungar.

"Daí, nóis si imbrenhô, i fumo saí na casa dum fazendêro pru nomi Vicente Malaquia. Tava lá um povão, com missa di festa. U padre Imídio tava lá, muito conhicido di nóis, apois era fio das bandas di Santo Antonho da Glóra. Armocemo cum u padre: Virgino, Lampião, Izequié, i êste seu criado Anjo Roque. Eu arresorvi me cunfessá mais u pade Imídio e me cunfessei, i êle mi disse:

- Num mate mais us macaco, meu fio. Nus mandamento tá pruibido. Quando pegá um, você cape êle, i sorte capado.

Como tudo aí era amigo, nóis discansemo, brinquemo, passemo u dia filiz, sem fazê má a ninguém" (44).

Em qualquer dos combates realizados, um lugar mereceu-lhes sempre muito respeito: as igrejas. Não se tolerava qualquer sacrilégio contra esses "lugares santos".

"Nóis arresorveu atacá (Mirandela). U pade tava na igreja dizeno missa. ra u sargento Guedes. Disparemo as arma, pra dentro da rua, qui istrondô $i$ avancemo pra frente.

Eu vim ficá di confronte u quarté, sendo a porta du quarté incostada na igreja. Nóis sempre arrespeitemo as igreja i us pade" (45).

75 .

(42). - Albuquerque (Ulysses Lins de), Um Sertanejo e o Sertão, pág.

(43) . - O Padre Bulhões de Santana de Ipanema foi o tutor de Sílvio, filho do casal de cangaceiros "Dadá" e "Corisco".

(44) - Lima (Estácio de), $O$ mundo estranho dos cangaceiros, págs. 114,115 a 282 .

(45). - Depoimento de "Labareda", in $O$ mundo estranho dos cangaceiros, pág. 232 . 
E quando morria um companheiro, em circunstância que permitisse uma cova, uma cruz tosca era colocada sobre a sepultura improvisada, para a "encomenda do corpo".

Depois, a cruz era retirada, porque ela poderia representar boa pista para o inimigo.

"Di noite, nóis abriu um buraco fundo num grotão da Serra, i interremo, bem interrado, u Sabino, in lugá quei ninguém mais nu mundo pode discubri pru querê"!

Quando Lampião chegô cumprimo u trato de treiz dia, tirô u chepéu, baxô a cabeça i rezô, prá ninguém iscutá, as reza qui êle sabia sê as mió i mais forte! (46).

\section{SUPERSTIÇÕES E CRENDICES.}

As superstições tinham fins utilitários, conquanto transmitidas, ou incorporadas, aos seus costumes, pelos cangaceiros, de maneira irracional, não deliberada .

O cangaceiro, quando surpreendido pela volante, deveria cortar a rede com seu facão, pois acreditava que se não o fizesse morreria. Essa superstição, aparente, esconde a necessidade de estar sempre alerta, armado e preparado para saltar. Além disso, era conveniente năo deixar nada para os soldados.

O mesmo ocorria em relação às alpercatas; calçando em primeiro lugar o pé esquerdo, se surpreendidos pelos "macacos", tornava-se mais difícil por-se em guarda. Zé Sereno afirma que, "quando vi o véio" calçando a alpercata no pé esquerdo eu disse: Tá morto. Eh! não se pode carçá primeiro o pé esquerdo não".

Diferente do que nos possa parecer, calçar primeiro o pé esquerdo não é conveniente, numa luta onde é preferivel sair descalço, ou colocar uma alpercata se for o caso, mas no pé que lhe dará equilíbrio e impulso de arranque, o direito.

Inúmeras as lendas que se formam com base nas crendices.

"Um homem sem cabeça que anda vagando pelas matas ou uma mulher que apareça enforcada ao pé de uma goiabeira ou ainda uma criança que morreu depois de uma surra".

As crendices populares, prodigiosas em imaginação, alimentavam as histórias fantásticas que mais serviam para robustecer o espírito

(46). - Lima (Estácio), ob. cit., págs. 226-227. 
supersticioso do povo. Essas "almas" voltavam à terra para cobrar a sanha dos seus matadores que não poderiam mais viver em paz e fatalmente se arruinariam.

"Durante vinte anos, Lucas foi o assombro, o pesadelo dos sertanejos. Contaram-se por centenas suas vítimas. O negro salteador, ladrão e assassino, raptou e violentou inúmeras donzelas, matando-lhes os pais e irmãos, se êstes ofereciam resistência à sua lubricidade.

Há uma lenda, segundo o qual Lucas começou a esmorecer no seu fadário repelente, depois que, ao passar pela sepultura duma virgem que assassinara e enterrara no mato, sentiu um perfume delicioso e viu de cima da cova levantar o vôo um bando gárrulo de pombas brancs. Isso lhe teria, desde então, irremediàvelmente quebrantado o ânimo feroz" (47).

O sertanejo é um povo que mergulha com incrivel facilidade nas crendices. Aceita e acredita, de igual forma, em todas as feitiçarias, crenças africanas, indígenas, mescladas à fé católica.

"U nêgo Tiburço um dia mandô recado prá nóis, dizendo que nóis era frôxo, i nu dia qui pegasse a gente dava na gente di chicote. U nêgo ôsado agravô us pessoá todo nu grupo, i Lampião mis danado ficô pruque Tiburço foi na fazenda dña viuva, tia di Virgulino Ferrêra, vurgo Lampião, deu u'a sóva na véia, tumô uns animá i inzijiu dois conto qui a véia teve di fazê, prá dá a Tiburço.

Nóis tava ua vêis in Pato, i Lampião tocô riuní dus minino, i chamô nóis prá í na fêra di Santa Maria, bebê uas i outa e fazê uns furdunço.

Nóis achô bom, i fumo prá Santa Maria.

Sabe Vossenhoria quem nóis incontrô in Santa Maria?

Apois foi isso mesmo, nóis topô u nêgo Tiburço qui cunhiceu log cumpade Lampião, i ficô cinzento, quaji branco, di mêdo.

Lampião avisô qui u nêgo se aperparasse prá dá conta naquela casião da surra qui deu na véia, dus animá qui robô $\mathrm{i}$ dus conto tumado.

Prá dizê certo, u nêgo Tiburço num era cangacêro di verdade. U qui êle vinha a sê, era sartiadô prá matá i robá.

Nóis fumo dentro dus cabra di Tiburço i matemo todos cinco, mas u nêgo si trincherô nu'a casa, i lá vai bala i mais bala dêle i du cumpade Lampião. U nêgo foi pipinado di tiro i gritava di dentro:

(47). - Lima (Estácio), ob. cit., pág. 271. 

cê quizé.

- Lampião, num mi mate qui vô mais você, prá donde vo-

- I minha tia, seu fio da peste?

Nisso, u nêgo Tiburço, todo baliado, correu i caiu nu rio, com tenção di fugi. Merguiava aqui, levantava depois a cabeça, i cumpade Lampião pôde fazê, afiná, pontaria, i Tiburço foi pro fundo sem vortá.

Cumpade Lampião mandô vê u’a vela, cendeu a vela dentro dña cumbuca de cabaça i sortô a cumbuca im riba d'água.

Nóis sábia qui si Tiburço tivesse morrido mesmo, a cabeça, cum a vela, parava nu lugá certo prá dá aviso. I parô num lugá, qui uns besta inda dissero, qui parô i tava rodano, pruquê tinha rimuinho dái água. Mas porém, u qui tinha era difunto nu fundo i Lampião mandô uns home merguiá, $i$ trazê u nêgo cumo tivesse.

I truvero mesmo, pruquê tinha di trazê. Tiburço tava bem matado i pipinado di bala.

Us povo qui viu tudo, afiná creditô na marcação da cumbuca i da vela" (48).

Não se tem conhecimento de que os cangaceiros recorressem aos curandeiros para livrar-se de seus males, mas a medicina rudimentar, que eles usavam, era essencialmente baseada na fé. Seus curativos, feitos muitas vezes com plantas medicinais, eram acompanhados de orações fortes para ajudar a cura do ferimento. Eles próprios usavam os métodos curandeiristas, o que aliás não é novidade, porque, no fundo, qualquer sertanejo conhece as rezas e as usa naturalmente.

"Permanecem todos os antigos bandoleiros que temos ouvido, certos de que nenhum dos homens dos grupos há sido jamais "mordido de cobra", a despeito do trânsito constante pelo reino das cascavéis, por serem, sem exceção, "rezados".

Adotavam, todavia, talvez sem o saber, certos cuidados higiênicos relativos, por exemplo, à tuberculose, uma vez que traziam, de ordinário, canecos, pratos, colheres, sem os misturarem, utilizando-os em carater estritamente individual: cada um com o que é seu (49). Tambem a dormida ao ar. livre, ou nas barracas, durante os temporais, há de ter sido útil, evitando os perigos do ar confinado...

O cangaceiro, acometido de blenorragia, com supuração constante, não tomava "banho de mergulho", nos poços estagnados, ou nos caldeirões:

(48). - Mota (Leonardo), ob. cit., pág. 46.

(49). - Lima (Estácio), ob. cit., págs. 273-274. 
"A doença àtaca os olhos, subindo prá cabeça, e cega àquele que desobedecer, baixando-se nu e molhando a cara"...

A ingenuidade aparente possuia, contudo, as suas razões. E que haviam observado casos de contaminação da vista, pela água parada onde caira, de certo, alguma gota de puz, naquela mesma hora... maiores.

As doenças venéreas constituiam, para eles, um dos tormentos

- "Reza, aqui não serve, porque a doença é feita..." (50).

"Os curativos de feridas eram feitos com umburana de cheiro e casca de angico. A casca cozida servia para lavar o ferimento. Colocava-se pimenta para evitar o tétano, e por cima uma compressa de mingau de fumo e farinha, protegida por um pano. Quando o ferimento já estava cicatrizando, a casca de angico era colocada sôbre o local atingido.

Para os casos de fraturas, os cangaceiros faziam uso de gravetos para encanar o local fraturado com pau faceiro velho, bem fininho, e uma espécie de esteirinha" (51).

O "impaludismo" ou "sezão" como eles chamam, era outra doença frequente no sertão e, consequentemente, entre os cangaceiros.

Para combater o mal eles costumavam cavar um buraco e, depois, recolocavam a terra retirada pronunciando a seguinte oração:
"Sezão ti interro aqui
Ti afasto de mim
Tu só torna vortá
Si di novo eu aqui vim!"

Em seguida, eles colocavam um feixe de lenha e, provavelmente, nunca mais voltariam ao lugar.

Quando a doença não cedia era porque o interesado não teria cumprido à risca

"o que foi mandado fazê ou entẳo porque êle teria passado pelo mesmo lugar onde "andou algun côrno". "Homem enganado por mulher só dá azar" (52).

(50). - Na realidade, a escassez de água dificultava a lavagem dos utensílios.

(51). - Lima (Estácio), ob. cit., págs. 130-131.

(52). - Depoimento de Hilda Ribeiro, vulgo "Sila". 
"Também faziam odontologia. Os melhores "dentistas" dos bandidos: Lampião, Zé Bahiano, Labareda, Virginio. As avulsões dentárias não as praticavam a boticão. As pontas dos punhais eram infalíveis alavancas. Jamais tiveram hemorragias depois dessas "operações". Processos inflamatórios bucais cediam aos "bochechos de mandacaru". Igualmente, rezavam. Raspa de juá domina as cáries. Apenas não realizavam próteses" (53).

O prestígio dos amuletos não caiu, jamais, em subestima, nas hostes do cangaço.

Uma das rezas preferidas pelo pessoal dos grupos, era a da "Pedra Cristalina". Pistoleiros atuais, igualmente, a tem na conta melhor, e pacatos sertanejos ainda hoje continuam a preserva-la na maior fé.

Não é preciso que uma oração, para produzir efeito, seja pronunciada, ou sequer conhecida no seu texto, pelo portador. Basta a permanência no pescoço, no bolso, ou na própria capanga, enrolada como um Agnus Dei, ou apenas dobrada. Lampião não abandonou, até a morte, a sua Pedra Cristalina.

As transcrições que se vão seguir, devemos à nímia gentileza de Theo Brandão, um dos maiores folcloristas contemporâneos...

Mas vamos, de imediato, apreciar toda a proteção espiritual do famigerado Senhor das Caatingas. Respeitamos, cuidadosamente, a forma, e, até, as palavras que surgiam pela metade, ou as falhas do texto

\section{DA PEDRA CRISTALINA.}

"Minha pedra christalina que no mar foeste achada entre o calix e a hostia consagrada, tremo a terra mas não treme nosso Senhor Jesus Cristo no altar assim treme os coração dos meus inimigos quando olharem para mim eu tibenzo em cruz inão tua a mim entre o sol ialua $\mathrm{i}$ as Estrellas as três pessoas distintas da Santíssima Trindade meu deus na Travissia avistei meus inimigos meu deus oqui fasso com êles com o manto da Virgem Maria sou cuberto e com o sangue de meu Senhor Jesus Cristo sou valido tens, vontade de atirar, porém não atira si mi atirar água

(53). - Depoimento de Ângelo Roque, vulgo "Labareda", e confronto com Estácio de Lima, ob. cit., pág. 133. 
pello cano da Espingarda correrá si estiver vontade de mifurá a faca da mão cahirá si miamarrar os nós dezatarão e si mitrancar as portas si abrirão.

offiricimento

"salvo fui salvu sou e salvo serei com a chave do sacrário eu me fecho".

1 PN 3 AM i 3 Glória apatre iofereço a 5 Chagas de Nosso Senhor Jesus Christo".

\section{DAS TREZE PALAVRAS DICTAS E RETORNADAS.}

"Digo uma

Uma é a Casa Santa de Jerusalém onde J C. Nasceu Duas são as duas taboas de Moisés que nosso Senhor Jesus Christo trouxe em seus sagrados pés. Três são os tres cravos que cravara J. C. na cruz Quatro são os quatro evangelistas S. João; S. Matheus, S. Marcos e S. Lucas.

Cinco são as chagas di meu Senhor J. C. Seis são os 6 filhos entos da Casa Santa de Jerusalém Sete são os 7 salmos di N. Senhora .

Oito são os 8 corpos santos da Caza Santa de Jerusalém 9 sã os 9 Côros de anjo qui para o céu subiu 10 são os 10 mandamentos de meu Senhor J. C. 11 são as 11 mil virgens qui estão em companhia de meu S. J. C. 12 são os 12 apóstolos di meu Senhor J. Christo 13 são os 13 reis qui parte tudo e arrebenta assim como eu ei de arrebentar ou partir o coração de fulano ou fulana.

Oferecido ao Senhor Livino Ferra di Soua

\section{DE NOSSO SINHOR JEZUZ CHRISTO.}

"Assim como vejo a luz do dia vejo meu Sinhor Jesus Christo e a irgem Maria tão grande on eu neste $\ldots \ldots \ldots \ldots \ldots \ldots$ como andou meu Sinhor Jesus Christo........... que fizessem Deus por mim ninguém contra mim corpo é sangue di meu Senhor Jesus Christo.

Ofericido ao Sr. Livino Ferreira da Silva Passagi das Pedras 3 de outubro de 1916" (54).

Essas orações foram encontradas nos bolsos de Lampião, logo depois de sua morte em Angicos.

Esse tipo de superstição está enraizada no epírito do sertanejo.

(54). - Lima (Estácio), ob. cit., pág. 134. 
"Não há povo cheio de crendices, mais propenso a acreditar em bruxedos, do que o sertanejo. Crê em tôdas as feitiçarias, por mais ignóbeis e estúpidas que sejam, misturando na sua prática crenças africanas, indígenas e européias, estas adquiridas por hereditariedade, aquelas pelo contato das raças. As reminiscências das bruxarias africanas e indígenas formam a base de tôdas as feitiçarias em que as européias aparecem apagadamente, com o seu cunho religioso velado pelo fetichismo das duas raças inferiores. Um tipo interessante sintetiza tôda essa inclinação e tôda essa ignorância - é o curandeiro.

No sertão, cada ribeira, cada região, cada povoado, tem o seu curandeiro - médico, e ignrante ao mesmo tempo. É quase sempre um negro idoso, sebento, embrutecido; ou um mestiço esquálido, sujo, com tiques nervosos no rosto, aspecto concentrado de quem vive recolhido na profundeza dos seus pensamentos, gestos vagos de assombro, sempre remoendo entre dentes frases ininteligiveis. Muitos, os mais afamados especialmente, têm atitudes impressionantes, voz imperiosa, gestos imperativos, modos fortes de comando.

Em casa vão consultá-lo para tudo: para curar bicheiras dos gados e doenças dos homens; para encontrar objetos ou adivinhar autores de furtos misteriosos, para salvar pessoas mordidas de cobra, levantar espinhas caídas, fazer passar dôres atrozes de dentes, achar lugares bons para cavar cacimbas e "curar" ou "fechar" corpos às facadas, às balas, à água e às prêsas afiadas das serpentes" (55).

\section{HONESTIDADE.}

O sertanejo tem padrões de honestidade que vem desde sua entrada no sertão. Essa honestidade, no tocante à propriedade, e aos bens materiais de outro, não é um valor totalmente subjetivo, antes é um valor objetivo, garantido ou preservado pela força coercitiva do Estado, ou do indivíduo. O vaqueiro partia com o gado do senhor de engenho para a caatinga, e deveria voltar para prestar contas. Não poderia manter-se no sertão, sem ter uma retaguarda no centro urbano, para suas necessidades. Desta forma, era forçado a ser honesto, para não cair no desagrado do senhor. No sertão mandava o mais forte em jagunços e armas.

O "coronel latifundiário" era o senhor de "baraço e cutelo". A violação de sua propriedade, ou de seus bens, era punida por ele mesmo, ou pelos agentes do Poder Público, com severas sanções.

(55). - Lima (Estácio), ob. cit., págs. 115, 117, 118-123. 
Parece-nos provavel que o temor do castigo sobreponha-se, no sertanejo, à sua própria miséria .

\section{Honestidade.}

Como pode um homem com padrões de honestidade, surgidos desde a época da colonização, tornar-se um cangaceiro e saquear cidades, roubar fazendas e extorquir dinheiro dos senhores de terra?

Enquanto se encontra servindo ao coronel, na condição de empregado, o sertanejo mantém seus padrões tradicionais de honestidade; altera-os no momento em que se envolve numa vida à margem da sociedade sertaneja; rouba do coronel, sob o pretexto de que está "pedindo", e porque não podia trabalhar.

Furta de homens que um dia foram seus patrões, e que hoje são patrões de outros sertanejos, e que, igualmente, um dia poderão tornar-se cangaceiros. Enquanto são empregados, e tem seus salários, nunca lhes passava à mente algo que pudesse - mesmo de maneira remota - justificar o roubo. Na condição de cangaceiros entretanto, e sem poder trabalhar - porque a engrenagem social os impede de fazer - roubam sabendo que seus antigos patrões, representados na figura de qualquer senhor dono de terras, "tem demais e podem nos dá um pouco".

E os cangaceiros faziam muito mais. Não roubavam dos pobres, e, muitas vezes, o produto do furto, efetuado contra os ricos, era distribuido com o povo.

Talvez, inconscientemente, eles visem, na figura do pobre, um homem como eles foram no pasado. E sentiam necessidade de ter o apôio e, principalmente, a simpatia desse povo que tem origens semeIhantes às deles. O jornal $A$ Tarde da Bahia, de 2 de janeiro de 1929, registrando uma pasagem de Lampião, publicou:

"Lampião é um cabloco inteligentíssimo. Compreendeu de logo a necessidade de ter rasgos de cavalheirismo que comparados aquelle tripúdio feroz sôbre as populações, estabelecesse um contrastre chocante e proveitosíssimo para si.

$E$ entrou a executar o plano delineado:

Certa vez bateu à porta de um casebre humilde.

- Ó de casa!

- $O$ de fora!

- Chegue à fala, creatura.

Saiu-lhe um velho, um desses typos venerandos de patriarchas, tão communs no sertão. 
- Vam'cê tem um bóde ahı, móde aprontá um de comê p'ra nóis?

- Tenho, nhôr sim...

O cangaceiro, prompta a refeição, comeu com os seus asseclas. $E$ ao levantar-se, depois de se benzer, indagou quanto custava aquillo.

- Um bóde é quatorze mil réis...

- Apois tome lá cinquenta, que é um mimo de Lampeão!

O sertanejo considerou-o com o olhar cheio de admiração.

E balançando a cabeça, com os dedos palpando a nota rara, desabafou por fim:

— E verdade! Dizem que vam'cê é que é ladrão e matadô... Vam'cê me compra um bóde e me paga o preço de um garrote... Os soldados ainda honte passaram aqui, comeram um carneiro, mataram us despotismo de gallinha e não pagaram, e ainda sairam me chingando!. . .

Lampião rugio; bruscamente:

- O quê houve?!

- E isso, confirmou o outro...

- E quanto foi a despeza dêlles?

- Uns trinta mil réis, capitão...

O cangaceiro despertou novamente a capanga e saccou a importância calculada. Estendeu-a ao ancião:

- Pégue, meu tio!

E num desalento immenso:

— Esses macaco só véve me fazendo vergonha".

O Jornal do Recife, edição de 3 de dezembro de 1914, publicava entrevista do cangaceiro "Baliza" que ao referir-se a Antônio Silvino, afirmava:

- "Antonio Silvino, eu nunca observei que tivesse sido má. Só assaltava quando precisava de dinheiro, e só tirava de quem tinha. Silvino pedia que lhe desse algum dinheiro porque o govêrno lhe esta movendo enorme perseguição e êle precisava de viver. Tôdas as pessoas, a quem Silvino procurava, ofereciam-lhe almôço ou jantar, e também aos que o acompanhavam, fornecendo-lhe cem, duzentos e até quinhentos mil réis".

"Antonio Silvino foi cangaceiro também, e, como rezam as historias de suas façanhas, protegia os pobres, dava esmolas, defendia os injustiçados. Devassava com os seus cabras, emboscando e, algumas vêzes, queimando as propriedades dos seus inimigos e matando-os também. Quando entrava numa fazenda, povoado ou vila, pedia apenas abastecimento para continuar a luta a fim 
de não ser capturado. Dos seus inimigos, porém, ele tirava vinganças muito duras" (57).

Dentro dessa mesma linha de raciocínio, vale citar um trecho da reportagem publicada pelo Jornal Correio de Aracajú, de 29 de novembro de 1929, e que fala da passagem de Lampião na cidade de Capela:

"Todo mundo queria ver, ouvir, dar dis deds de prsa com o célebre campeador nordestino e era, immediatamente, attendido com satisfação.

Lampeão, se bem que inculto, é, não resta dúvida, um sujeito arguto e intelligentíssimo.

Sejamos imparciais e justos - os nossos últimos e indesejáveis visitantes, pelo trato ameno, pela atenção e cordialidade, deixaram boa impressão ao público" (58).

A passagem de Lampião, por Juazeiro do Ceará, provocou as mais variadas reações, porque para alguns não houve melhor oportunidade do que aquela para a prisão do cangaceiro.

Mas Padre Cícero não quis por, na cadeia, Lampião, que se apresentava em Juazeiro por confiança, isto é, tinha sido convidado por Floro Bartolomeu.

Não se tem conhecimento de que algum dia um cangaceiro tenha "pedido", através dos seus famosos bilhetes, qualquer importância a um sertanejo pobre. As "solicitações" eram feitas sempre aos donos de terra, aos prefeitos (para que arrecadassem a quantia na cidade), ou a grandes negociantes.

"Ilmo. sr.

Sua saudações com todos lhe faço. Esta somente para lhe pedir 3 conto, de reis, apois seio qui OSenhor não Ignora Eu pedir e so peço a quem tem, por esto mutivo espero sem falta aresposta entregue a seu vaqueiro.

agora faça poco e alarmi a pulicia,

Resposta com toda

Urgença

Eu Capitão

Virgulino Ferreira, Lampião

(56). - Barroso (Gustavo), págs. 146-147.

(57). - Nonato (Raimundo), Lampião em Mossoro, pág. 112.

(58). - Jornal Correio de Aracajú, sexta-feira, dia 29-11-1929. 
"Ilmo. Sr. Cel. Antonio Franco

Espero qui esteja gozando de bóa saudi. Cel mando-lhe esta para acabarmos o noç negócio Ele bem sabi, apois esta com muito tempo Que pedi $\mathrm{E}$ gentil Eu receber nada pa tanto... espero agora com toda urgença o quantia oSr. Ja sabe qui $\mathrm{E} 5$ conto resposto pois esperando Mande com.. espero, confio $\mathrm{oSr}$ não faltado C 5 obr.

Cap ${ }^{9}$ Virgulino Ferreira (Lampião)

(N. A.) - Nesta carta de Lampião, feita do próprio punho, a coronel Antonio Franco, da usina Central em Sergipe, vê-se perfeitamente onde êle pede para com o "nosso negócio". Lampião achava que extorquir dinheiro dos coronéis era um negócio como outro qualquer" (60).

Se houvesse a recusa "nós era obrigado a ir buscá, porque a gente num pudia trabaiá, e quando faltava dinheiro a gente ia apanhá de quem tinha" (61).

Às vezes o bilhete era substituido pelo emissário direto, um cangaceiro mais jovem e com menor fama na região:

"Queremos dinheiro. Somos emissários de "Lampeão" e viemos buscar seis contos de réis. Caso contrário, a sua vida.

Deante disso, o sr. Francisco Alves preferiu desembolsar o seu dinheiro a perder a vida.

Os bandidos de posse dos cobres, sairam correndo, promettendo voltar. O prejudicado, temendo, de uma hora para outra, perder também a vida, fugiu com sua família para Villa Rica, onde se encontra" (62).

As circunstâncias levavam os cangaceiros a agirem dessa forma; eles não roubavam - pediam - era uma forma de mistificar a antiga honestidade. Ora, se eles pedem, não roubam, e se não roubam, não são ladrões. O histórico da personalidade de cada cangaceiro explica essa atitude, e essa nova maneira de agir.

Quando Lampião entrava numa cidade, procurava o prefeito e pedia-lhe que fizesse uma lista de homens ricos que pudessem dar dinheiro.

(59). - Prata (Ranulpho), op. cit., pág. 174.

(60). - Gois (Joaquim), Lampião, o último cangaceiro.

(61). - Depoimento de Guilherme Alves, vulgo Bala.

(62). - Jornal A Tarde da Bahia - 8-4-31. 
"Antão Correa, prefeito de Capela foi recebido por Lampião que the disse desejar entrar na cidade sem outro intuito que o de angariar uns cobres, prometendo não commeter depredações...

Mandou logo que o intendente organizasse a lista das pessoas que deviam entrar com o dinheiro, exigindo, porém, quantia não inferior a 20 contos. O entendente fez-lhe ver a impossibilidade de arranjar-se aquella quantia, visto o commercio estar exhausto e estarmos sendo perseguidos por tres annos de secca. Diante desta ponderação Lampeão respondeu:

- E, major, eu também venho atravessando u'a secca de 14 annos. Arranje pelo menos. uns seis contos".

Depois de ter comparecido à presença de Lampeão, por exigência dêste, o delegado de Polícia, foi-se tratar de arranjar, entre negociantes e uzineiros a importância exigida - Não se encontrou má vontade". (63).

O mesmo aconteceu na cidade de Cumbe, onde o prefeito Luiz Caldeirão recebe o cangaceiro que foi logo dizendo:

- Seu delegado, a gente vive viajando, precisa de dinheiro. Vou fazer uma lista para o senhor conseguir dinheirosinho pra mim.

- Tá certo, respondi! Ele me fez o pedido às 11 horas, e já ao meio dia, me perguntava:

- Cadê a lista!

Eu disse que não havia sido providenciada ainda. As duas da tarde insistiu:

- Como é que vai a lista?

Aí eu tive de explicar direitinho as coisas. Falei prá êle:

- Capitão Lampeão, voce anda viajando e passa aqui bem n momento da festa de Nossa Senhora, as ruas estão tôdas embandeiradas. Você podia dispensar êsse negócio. Assim não fica muito bem. Você com a lista e nós hoje com duplicata prá pagar. Os negócios tão fracos. O senhor não acha bom assim?

Ele olhou prá mim, e disse: Acho sim, me dê a lista".

Eu dei e êle rasgou. Não demos nada a êle, mas depois chegou aqui um pessoal do coronel Bebé e o irmão de Lampeão pediu 100 mil réis. Ele deu duzentos e ficaram satisfeitos" (64).

(63). - Jornal $A$ Tarde da Bahia - 24-4-29.

(64) - Depoimento do ex-prefeito de Cumbe, hoje Euclides da Cunha, Luiz Caldeirão. 
Dentro dos padrões de honestidade dos cangaceiros estava o da palavra empenhada. Os chefes de bandos, recebendo influência direta de Lampião, não admitiam e não aceitava o "homem de duas palavras".

"Num precisa dicumento nem iscrituras pro mode garanti as palavras" (65).

São muitas as passagens que revelam esse comportamento dos cangaceiros:

"Lampião estava à procura de Juvêncio Texeira para matar êle... Esse homem se escondia pela cidade fugindo de Lampião. Um dia, Juvèncio pediu a dona Déia, mãe de Maria Bonita, para implorar a Lampião que não matasse êle. Numa Semana Santa que Lampião passou com dona Déia, ela pediu a êle um favor.

- Faço, disse Lampião mas só se disser o que é.

- Não senhor, só digo se prometer que faz logo. .

Todo dia a mãe de Maria voltava com essa história, e êle sempre falava:

- Quando falá o que é eu digo se faço ou não.

No sábado de Aleluia, êle ia embora, selou os burros e Dona Déia disse:

- Você nunca me atendeu num pedido, também não lhe faço nunca outro.

Lampião respondeu:

Diga Déia, que eu faço.

- O que eu quero é que dispense Juvencio Teixeira. Num matá o homem não.

Lampião botou a mão na cabeça e disse:

- Ah! Juvenció Teixeira feliz dos diabos. Diga a êle que se ajoelhe a seus pés todo dia, e lhe chame de mãe Déia, e diga a êle que pode dornir na estrada que não vou bolir mais com êle".

Juvêncio vive por essas bandas até hoje (66) .

\section{(Continua) .}

(65). - Expressão usada ainda hoje pelos antigos cangaceiros.

(66) . - Depoimento de José Maria de Souza, ex-coiteiro, atualmente residindo na cidade de Santa Brígida, Estado da Bahia. 